\title{
PENINGKATAN PELESTARIAN SENI TARI WAYANG ORANG MELALUI VIDEO PEMBELAJARAN
}

\author{
Elta Sonalitha $^{1)}$, Sari Yuniarti ${ }^{2)}$, Bekti Prihatiningsih ${ }^{3)}$, Arya Yuda Prasetya ${ }^{4)}$ \\ ${ }^{1)}$ Fakultas Teknologi Informasi Universitas Merdeka Malang \\ ${ }^{2)}$ Fakultas Ekonomi Universitas Merdeka Malang \\ ${ }^{3}$ Fakultas Teknik Universitas Merdeka Malang \\ ${ }^{4)}$ Global Cinema Malang \\ E-mail : elta.sonalitha@unmer.ac.id
}

\begin{abstract}
Abstrak
Kekayaan Bangsa Indonesia dengan keanekaragaman budaya sangat perlu untuk dilestarikan. Seni wayang orang merupakan salah satu jenis dari sekian banyak ragam jenis budaya di pulau Jawa. Wayang orang sejatinya adalah seni yang mempunyai nilai-nilai luhur dalam pementasan maupun dalam ceritanya, dalam pementasan wayang orang disajikan cerita-cerita yang penuh dengan nasehat-nasehat budi pekerti luhur.

Semakin langkanya pengajar tari dan minimnya pelaku tari senior yang mempunyai multi talenta, menyebabkan kelangsungan budaya tari terancam punah khususnya tari wayang orang. Solusi yang ditawarkan adalah merancang sistem pembelajaran yang diharapkan mampu menunjang proses belajar mengajar dan menunjang pelestarian seni tari wayang orang yaitu pelatihan pembuatan video bagi pelaku seni, membuat video pengajaran tentang kesenian khususnya video pembelajaran tari klasik wayang orang secara step-bystep.
\end{abstract}

Kata Kunci: budaya, sanggar tari, wayang orang, pelestarian,video pembelajaran

\section{PENDAHULUAN}

Seni wayang orang sejatinya adalah seni yang mempunyai nilai-nilai luhur dalam pementasan maupun dalam pembuatannya. Dalam pemantasannya disana disajikan cerita-cerita yang penuh dengan nasehat-nasehat budi pekerti luhur, serta karakter di setiap tokoh ceritannya. Latihan tari wayang orang dibutuhkan kesabaran serta ketekunan bagi pengajar juga pelajar. Seni wayang orang penting untuk membentuk suatu karakter terutama untuk generasi muda sekarang ini.

Dewasa ini kondisi wayang orang itu sendiri sering di abaikan oleh sebagian besar para generasi muda, bahkan anak muda sekarang lebih memilih budaya luar dibanding mencintai budaya lokal. Contohnya anak muda sekarang sering menonton film-film luar negeri, music modern, bermain game, media social dan sebagainya, daripada menonton pementasan wayang orang, ketoprak, memainkan gamelan atau hal yang berhubungan dengan budaya lokal. Hal ini sangat dikhawatirkan kelestarian budaya tari tradisional terutama

wayang orang ini akan punah dan generasi yang akan datang tidak akan mengenal apa itu kesenian tradisional terutama wayang orang.

Berdasarkan observasi yang kami lakukan di Kecamatan Singosari Kabupaten Malang dan Kecamatan Junrejo Batu, kondisi sanggar tari wayang orang jawa masih relatif baik, namun kegiatan latihan tari hanya diadakan pada saat-saat akan terjadi pementasan saja, di samping itu peminat terhadap seni tari semakin jauh berkurang. Pengetahuan masyarakat tentang tokoh dan cerita wayang orang yang masih awam serta minimnya partisipasi masyarakat untuk ikut melestarikan seni tari ini menyebabkan sanggar tari tidak berkembang dan cenderung mengalami kemunduran seperti mati segan hidup tak mau. Kondisi ini sangat memprihatinkan sehingga diperlukan upaya maksimal untuk membangkitkan kembali sanggar tari tersebut .

Strategi yang diusulkan untuk membantu dalam pelestarian budaya seni tari sebagai aset bangsa adalah mengadakan pelatihan pembuatan video bagi pelaku seni, membuat video pengajaran tentang kesenian khususnya video seri latihan tari wayang orang secara step-by-step, membuat web interaktif sebagai media konsultasi para pelajar tari melalui internet, memproduksi secara masal video pengajaran tari wayang orang dan membuat website sanggar tari wayang orang sebagai media publikasi online sehingga penyebaran budaya tari mempunyai jangkauan yang lebih luas.

Banyaknya sanggar tari yang akhirnya gulung tikar karena kurangnya eksistensi yang disebabkan oleh kurangnya publikasi secara luas. Sehingga secara rinci, beberapa permasalahan yang dihadapi (dan disepakati oleh kedua belah pihak untuk dibantu), antara lain: 
1. Pelaku seni tari wayang orang dengan multitalenta sudah langka.

2. Kebanyakan pelaku seni tari hanya ahli pada satu bidang seni saja, misalkan tari laki-laki, tari perempuan, atau salah satu alat musik gamelan saja. Pelaku seni multitalenta yang menguasai tari gagahan (laki-laki), tari putri (Perempuan) dan Tari anak-anak sekaligus sudah langka ada di Kota Malang dan Kota Batu.

3. Terbatasnya penyebaran informasi tentang eksistensi pelaku seni tari wayang orang.

4. Proses penyebaran informasi juga sebagai ujung tombak kelestarian budaya terutama seni tari wayang orang, adanya dokumentasi yang bagus dan media promosi yang tepat kurang dipunyai oleh mitra saat ini.

5. Terbatasnya waktu pengajaran tari langkah demi langkah terjadi berulang-ulang untuk murid yang tersebar di beberapa tempat.

6. Pelayanan guru tari selain mengajar di dalam sanggar, juga diluar sanggar terkadang terjadi di beberapa tempat dengan permintaan tarian yang sama.

Sanggar Tari Talkhondho dibawah pimpinan Ki Iksun ini terdiri dari Ki Iksun sebagai pimpinan, 5 orang pelatih tari dan mempunyai beberapa grup murid tari mulai dari anak-anak sampai dewasa. Grup anak-anak terdiri dari 15 sampai 20 orang anak, sedangkan grup dewasa rata-rata terdiri dari 5 sampai 8 Orang. Ki iksun piawai dengan semua jenis tari jawa, namun lebih berkonsentrasi untuk jenis tari dan pementasan wayang orang sebagai pelatih, sutradara dan penyedia pakaian wayang orang. Pementasan yang rutin digelar di lokasi wisata cagar alam dan budaya kaliandra Sukorejo, Acara tahunan Malang Tempoe Doeloe yang diselenggarakan dalam rangka hari jadi kota Malang dan pementasan-pementasan atas permintaan organisasi masyarakat.

Ki Iksun beserta istri sejak usia dini sudah berkecimpung dan mengabdi di kesenian tari tradisional. Beberapa kota di Jawa pernah ditinggali selama profesinya di bidang seni. Ki Iksun merupakan salah satu dari para senior guru tari yang ada di kota Malang. Keahlian yang dipunyainya sudah sangat langka.

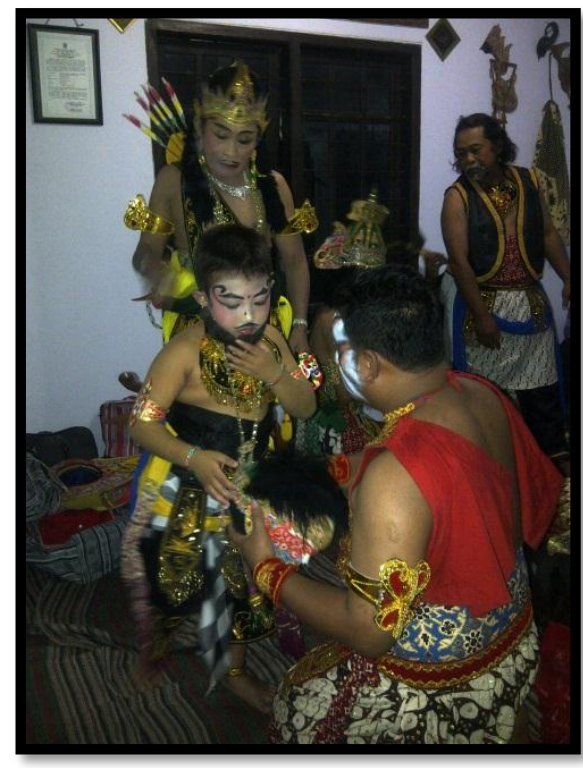

Gambar 1. Inspirasi Wayang Orang

Bapak Eko berlatarbelakang keluarga seni jawa, ayahnya seorang Dalang ternama di kota Malang, dan ibu nya mempunyai keahlian penyanyi (Sinden) dan keahlian di bidang musik gamelan (pengrawit). Bapak eko dengan keahliannya mempunyai murid-murid tidak hanya untuk kesenian tari wayang orang (6 Murid anak-anak dan 2 orang dewasa) saja, tetapi juga pedalangan (3 Orang Murid Anak-anak) dan musik gamelan (1 grup Karawitan). Budaya jawa yang mendarah daging pada dirinya, menyebabkan semangat Pak Eko untuk terus melestarikan budaya Jawa. Latihan diadakan di dalam maupun diluar sanggar, dikarenakan memenuhi permintaan lokasi murid.

\section{METODE KEGIATAN}

Strategi pelatihan lebih banyak menyajikan tata cara pembuatan video pengajaran, sehingga diharapkan dapat dijadikan media belajar yang mudah dan tidak terbatas tempat. Video pengajaran tari ini diharapkan mampu membangun komunikasi searah yang baik antara guru dan murid untuk bersama-sama memperlancar proses belajar mengajar.

Langkah-langkah pelaksanaan :

1. Melakukan pelatihan Story Board dalam pembuatan video pengajaran.

2. Melakukan pelatihan Perekaman Video untuk pengaturan musik, durasi dan bagaimana menyampaikan alur cerita yang runtut.

3. Melakukan pelatihan Editing Video juga cara memantau keberhasilan murid dalam menyerap ilmu tari yang diberikan. 
4. Melakukan pelatihan Finishing Video .

5. Melakukan pendampingan dan monitoring terhadap publikasi video pengajaran.

\section{HASIL DAN PEMBAHASAN}

a) Pelatihan Penentuan Ide (Tari Klasik), riset materi, Penyusunan Story Board dan Penyusunan Shooting Script.

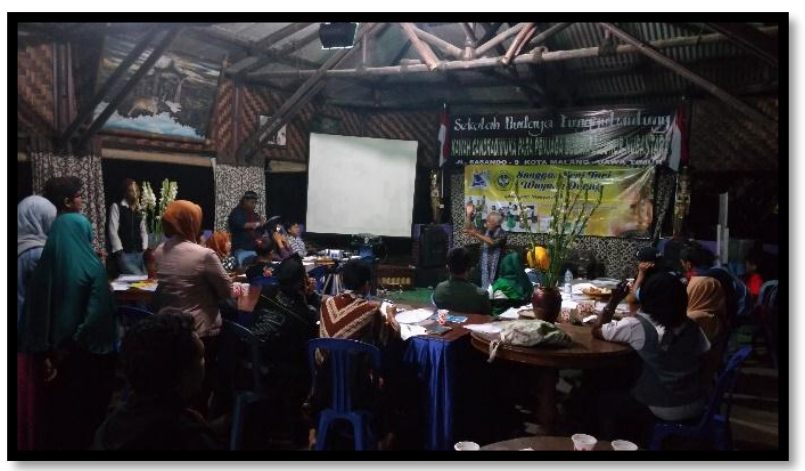

Gambar 2. Demo Tari Klasik sebagai Bahan Video Ajar

Pelatihan penyusunan Ide dan Shooting script ini dilaksanakan pada hari Kamis tanggal 25 Mei 2017 di Kelurahan Tunggulwulung kecamatan Lowokwaru Kota Malang . Pelatihan diikuti oleh 25 orang pengajar Seni dari kota Malang termasuk mitra pengabdian. Kegiatan pelatihan ini dimaksudkan untuk memunculkan ide dan menuliskannya dalam rancangan cerita yang akan dituang di video pembelajaran Tari Klasik. Diharapkan setelah mengikuti pelatihan peserta mampu menentukan sendiri tari klasik apa yang akan di video kan dan mampu merencanakan setiap gerakan dan durasi yang akan ditampilkan di video pembelajarannya.

Tahapan-tahapan dalam membuat Story Board adalah sebagai berikut :

1. Menentukan ide meliputi :

$$
\begin{array}{ll}
\text { - } & \text { gagasan awal } \\
\text { - } & \text { judul } \\
\text { - } & \text { riset/research } \\
\text { - } & \text { alur cerita } \\
\text { - } & \text { storyline }
\end{array}
$$

2. Materi Type of Shot (Tipe Pengambilan Gambar)

3. Praktek membuat Story Board

4. Praktek Membuat Shooting Script

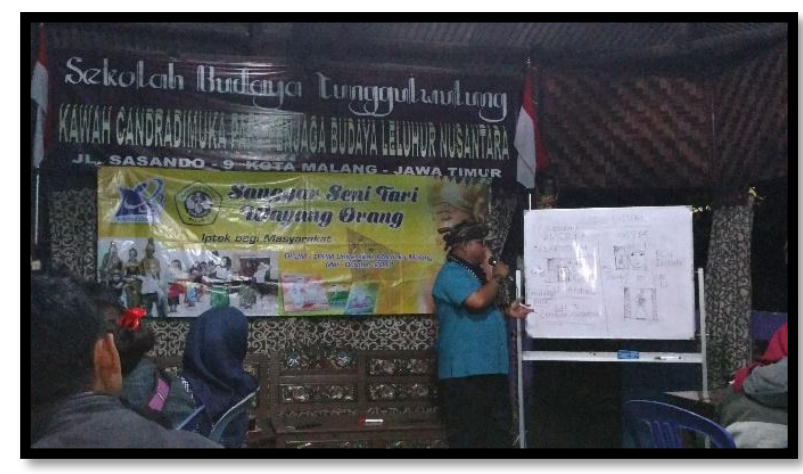

Gambar 3. Materi Tentang Audio Visual

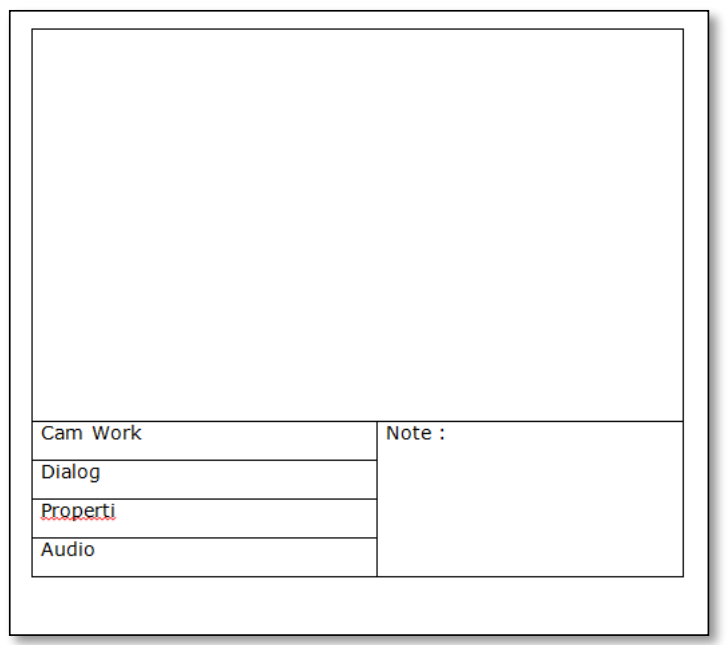

Gambar 4. Media Penulisan StoryBoard / Shooting Script

Beberapa item yang harus direncanakan dalam Story Board secara Umum seperti pada gambar 4

Proses Pembuatan Video Pembelajaran, hendaknya menggunakan Shooting Script. Begitu pula pada saat membuat Film Dokumenter.

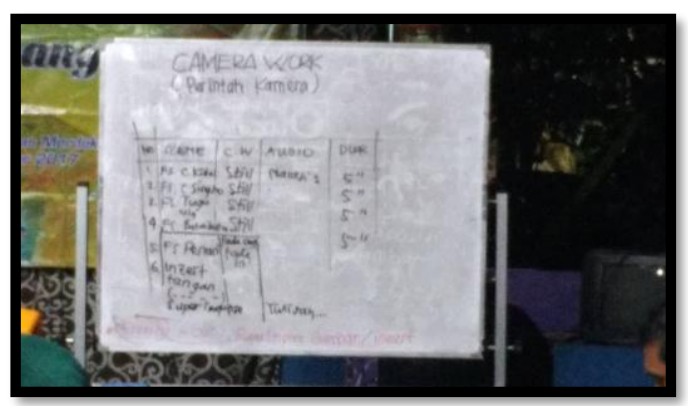

Gambar 5. Contoh Shooting Script

Hal ini dikarenakan, Story Board seringkali digunakan untuk membuat Karya Film dan lebih lengkap konten order (keterangan perintah pengambilan gambarnya). Sedangkan shooting script lebih simpel, lebih mudah dimengerti dan lebih mudah dipahami oleh editor. 
b) Pelatihan Teknis Produksi, (a) Evaluasi Shooting Script yang Sudah dibuat, (b) Materi type of shoot dan (c) Pengambilan Gambar/Lighting

Pelatihan Teknis Produksi ini dilaksanakan pada hari Sabtu tanggal 27 Mei 2017 di Kelurahan Tunggulwulung kecamatan Lowokwaru Kota Malang. Pelatihan diikuti oleh 23 orang pengajar Seni dari kota Malang termasuk mitra pengabdian.

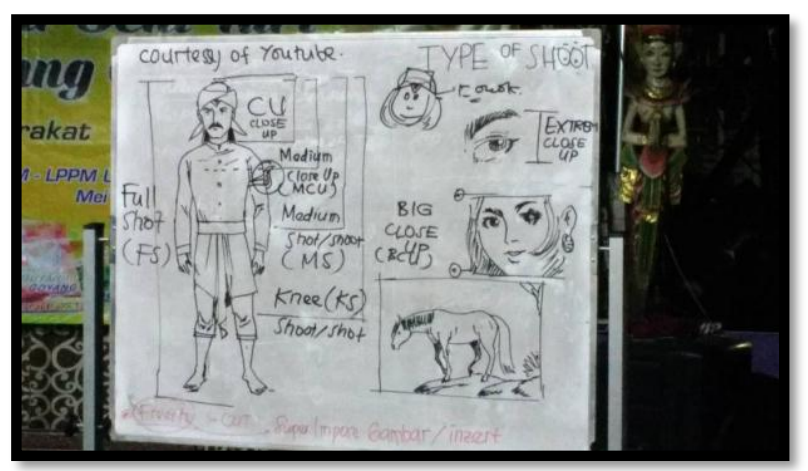

Gambar 6. Materi Type Of Shoot dan Camera Order

Kegiatan pelatihan ini dimaksudkan untuk mengetahui beberapa type pengambilan gambar pada saat memuat video pengajaran, agar pembelajarannya tersampaikan dengan baik kepada pemirsa. Diharapkan setelah mengikuti pelatihan peserta mampu memfokuskan kamera pada gerakan-gerakan yang diajarkan dalam video pembelajarannya

\section{- Pelatihan Type Of Shot and Camera Order}

Sebelum mengambil gambar, ada beberapa hal yang harus diperhatikan, diantaranya adalah mengetahui type of shot dan camera order. Secara Etimologi Bahasa, Type of Shot terdiri dari 2 kata.

Type berarti Tipe atau Model atau Jenis, Shot berarti tembakan atau Bidikan. Secara Umum, Type of Shot berarti Tipe atau Jenis Bidikan pengambilan Gambar/Obyek.

Secara Etimologi bahasa, Camera Order terdiri dari 2 kata. Camera berarti alat untuk merekam gambar. Order berarti Perintah atau Permintaan. Secara Umum, Camera order berarti daftar permintaan dan perintah sutradara kepada kamerawan (petugas pengambil/perekam gambar).

Alat dan Bahan

1. Kamera

(DSLR,POKET/MIRORLESS,SmartPhone dll)

2. ThreePOT

3. Perlengkapan Tata cahaya (Lampu, Reflektor/pemantul Cahaya) - Tidak Mutlak harus ada
Type Of Shoot:

1. CLOSE UP (Kode CU), yaitu pengambilan gambar obyek yang meliputi wajah secara keseluruhan. Ujung Rambut dan Ujung dagu tetap diperlihatkan utuh

2. MEDIUM CLOSE UP (Kode MCU) yaitu Pengambilan gambar obyek yang meliputi kepala secara utuh hingga bagian bawah dada

3. MEDIUM SHOT (Kode MS) yaitu pengambilan gambar obyek yang meliputi kepala secara utuh hingga pinggang/pinggul

4. Knee Shot (Kode KS) yaitu pengambilan gambar obyek yang meliputi kepala secara utuh hingga lutut (knee)

5. FULL SHOT (Kode FS) yaitu pengambilan Gambar obyek yang meliputi kepala secara utuh hingga terlihat kaki secara utuh (seluruh bagian tubuh)

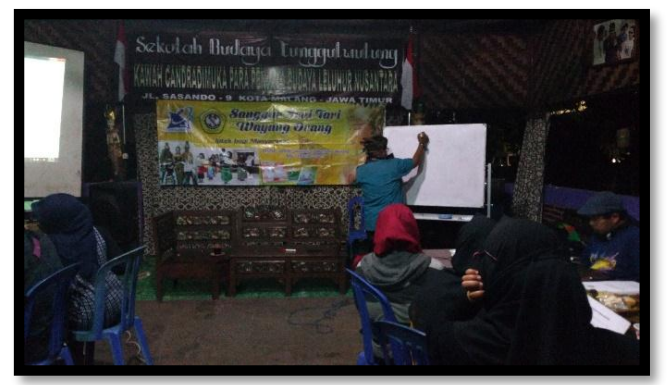

Gambar 7. Pelatihan Type Of Shot dan camera Order

Macam macam perintah atau CAMERA ORDER

1. STILL (Kode S) atau (Tetap/Diam), yaitu kamera dipasang di Tripot dalam kondisi tidak boleh digerakkan atau tanpa perintah gerak

2. PANN (Kode $\mathrm{P}$ ) yaitu pergerakan kamera (dengan posisi di atas Tripot) yang meliputi ke kiri dan ke kanan (istilah jawa : Noleh). Pann ada 2 jenis perintah yaitu Pann Right (Noleh kanan) dan Pann Left (Noleh Kiri)

3. TILL (Kode T) yaitu pergerakan kamera dengan posisi kamera di atas tripot yang meliputi ke atas dan kebawah.

Till ada 2 jenis perintah. Till Up (Kode T/U) yaitu perintah Kamera dari posisi standar/still mengarah ke atas (istilah jawa : Ndangak) dan Till Down (Kode T/D) yaitu perintah Kamera dari posisi standar/still mengarah ke Bawah.

Beberapa Catatan yang harus diperhatikan oleh peserta pelatihan antara lain :

1. Sebelum proses pengambilan Gambar, hendaknya kamerawan memperhatikan dan menyiapkan 
komposisi dan tata Letak atau penempatan kamera

2. Kamera sebaiknya tidak di letakkan di belakang obyek

3. Pahami perintah perintah pengambilan Gambar

4. Perhatikan Komposisi gambar

5. Setelah proses pengambilan gambar selesai, hendaknya di cek ulang atau dilihat kembali.

\section{- Pelatihan Pengambilan Gambar dan Pencahayaan}

Pelatihan Perekaman ini dilaksanakan pada hari Minggu tanggal 28 Mei 2017 di Kelurahan Tunggulwulung kecamatan Lowokwaru Kota Malang. Pelatihan diikuti oleh 16 orang pengajar Seni dari kota Malang termasuk mitra pengabdian. Kegiatan pelatihan ini dimaksudkan untuk praktik merekam gambar atau mulai membuat video pengajaran. Diharapkan setelah mengikuti pelatihan peserta mampu merekam setiap gerakan dengan baik dan mengatur pencahayaan yang tepat untuk video pembelajarannya.
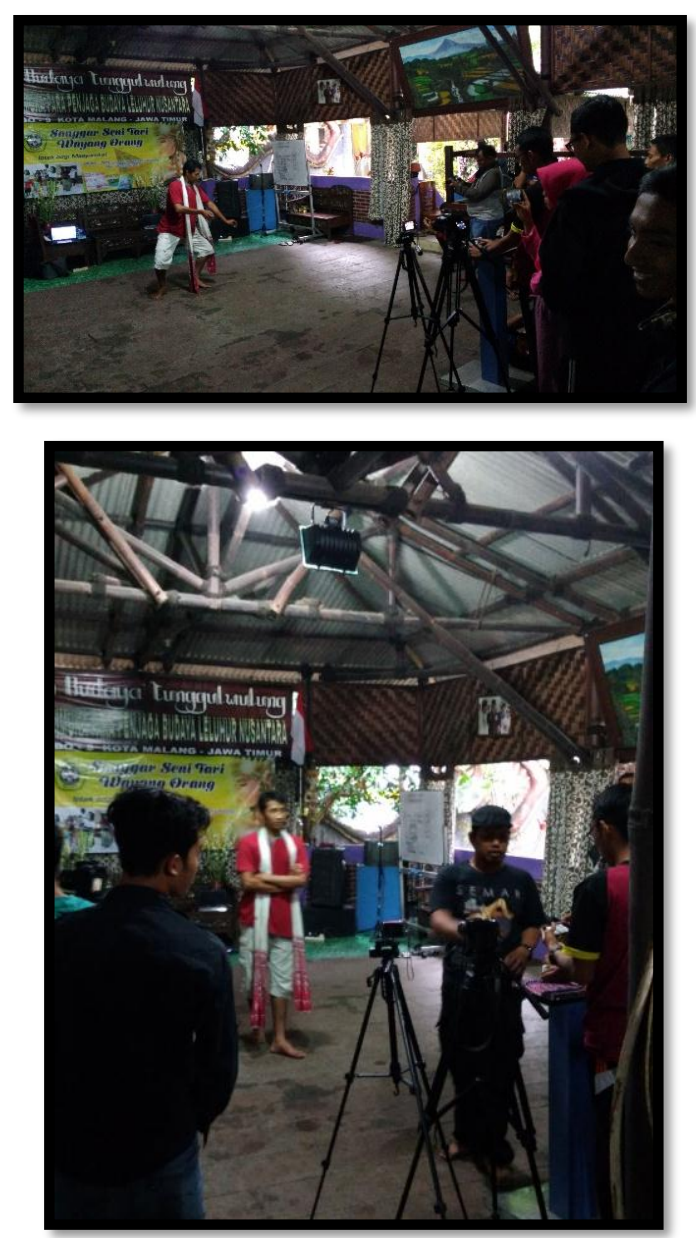

Gambar 8. Pelatihan Pengambilan Gambar dan Tata Cahaya

\section{- Pelatihan Editing}

Pelatihan Editing ini dilaksanakan pada hari Kamis tanggal 01 Juni 2017 di Kelurahan Tunggulwulung kecamatan Lowokwaru Kota Malang. Pelatihan diikuti oleh 16 orang pengajar Seni dari kota Malang termasuk mitra pengabdian. Kegiatan pelatihan ini dimaksudkan untuk praktik editing video. Diharapkan setelah mengikuti pelatihan peserta mampu mengedit hasil rekaman dengan baik dan mengatur audio yang tepat untuk video pembelajarannya.

Setelah melalui tahapan pengambilan gambar, maka file hasil tersebut akan dijadikan karya yang menarik. Tentunya ada beberapa tahapan sehingga file tersebut menjadi hasil video utuh yang menarik.

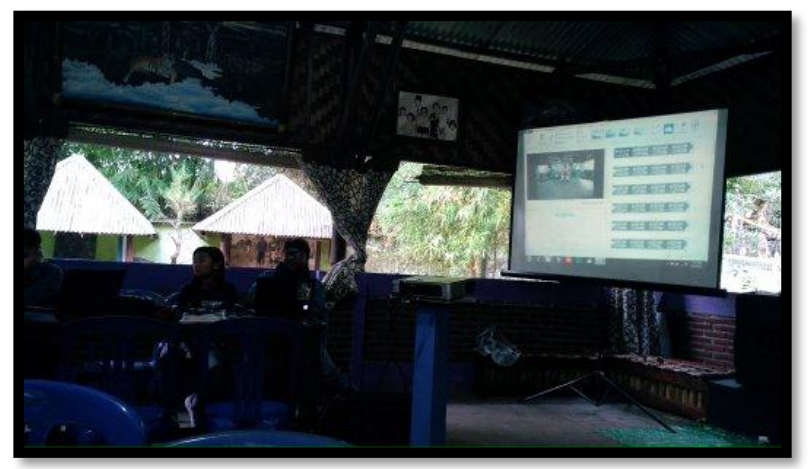

Gambar 9. Pelatihan Editing Video

Editing secara etimologi bahasa berarti EDIT yang berarti pengerjaan, penyempurnaan sedangkan Imbuhan ING berarti proses.

Menurut pengertian Multimedia secara umum, EDITING berarti proses atau tahapan pengerjaan sesuatu dari kondisi semula (biasa) menjadi lebih bagus dengan menambahkan keterangan baik itu tulisan, gambar maupun suara.

Alat dan Bahan

1. Komputer (PC) atau Laptop

2. Kabel data dari kamera ke PC/Laptop

3. Card Reader/ MMC

4. Headset MIC

Jenis Perpindahan Gambar / video pada Proses Edit 1. Perpindahan gambar hendaknya dilakukan secara CUT to CUT. CUT to CUT berarti memotong secara frontal/tegas. Pada jenis video Tari Klasik atau Modern, CUT to CUT dilakukan dengan cara mengikuti bunyi Gong ataupun Kendang

2. Perpindahan gambar secara DISSOLVE, berarti Hilangnya gambar pertama diikuti munculnya 
gambar kedua. Istilah Dissolve berarti juga Fade Out (hilangnya) video pertama secara perlahan dengan diikuti Fade In (kemunculan) gambar/ video kedua secara perlahan.

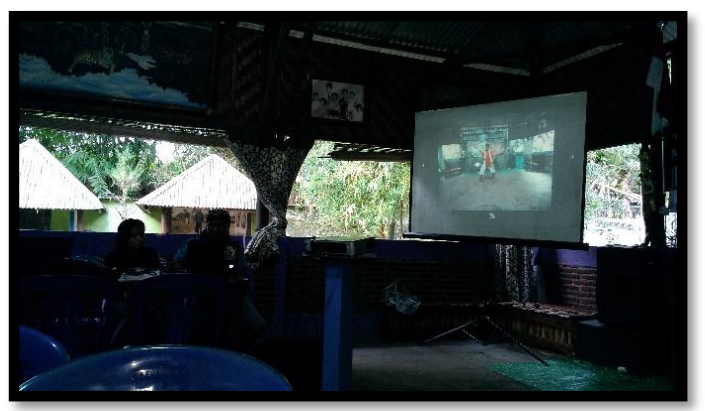

Gambar.10 Editing Video Penambahan Audio dan Teks

- Penambahan Audio dan Teks ke dalam Video

Backsound atau audio pengiring sebagai background video juga bisa ditambahkan dalam proses edit hasil video. Begitupula dengan penambahan Title atau Teks keterangan gambar.

Beberapa catatan yang harus dipahami peserta antara lain hasil Editing hendaknya meliputi :

a. Countdown Video (boleh diberi dan boleh Tidak)

b. Judul (video tutorial tentang apa, atau video pembelajaran apa)

c. Nama Sanggar yang mempersembahkan

d. Nama orang yang mempraktekkan / praktisinya

e. Nama Kerabat Kerja

\section{- Pelatihan Finishing Video}

Pelatihan Finishing ini dilaksanakan pada hari Kamis tanggal 08 Juni 2017 di Kelurahan Tunggulwulung kecamatan Lowokwaru Kota Malang. Pelatihan diikuti oleh 20 orang pengajar Seni dari kota Malang termasuk mitra pengabdian. Kegiatan pelatihan ini dimaksudkan untuk praktik penyempurnaan video dan pengemasan dalam bentuk Compact Disk (CD). Diharapkan setelah mengikuti pelatihan peserta mampu mengemas hasil rekaman dengan baik dan membuat cover yang menarik untuk video pembelajarannya.

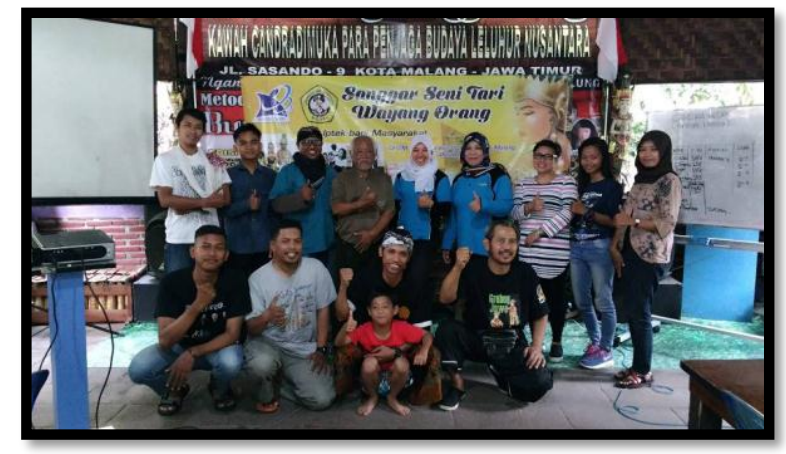

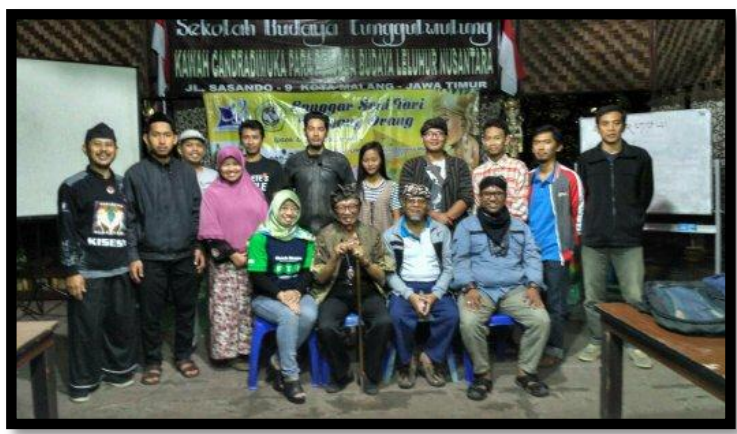

Gambar 11. Pengabdi dan Peserta di Akhir Pelaksanaan Pelatihan

\section{- Produksi Video untuk 2 Sanggar Mitra}

Produksi ini dilaksanakan pada hari Kamis tanggal 18 Juni 2017 di Lokasi mitra Bondhan Wibatsyuh Kelurahan Karangploso Kecamatan Ngijo Kabupaten Malang. Produksi dilakukan oleh 3 Penari, 2 dari Sanggar Bondhan Wibatsyuh dan 1 dari sanggar Talkhanda yang merupakan mitra pengabdian.

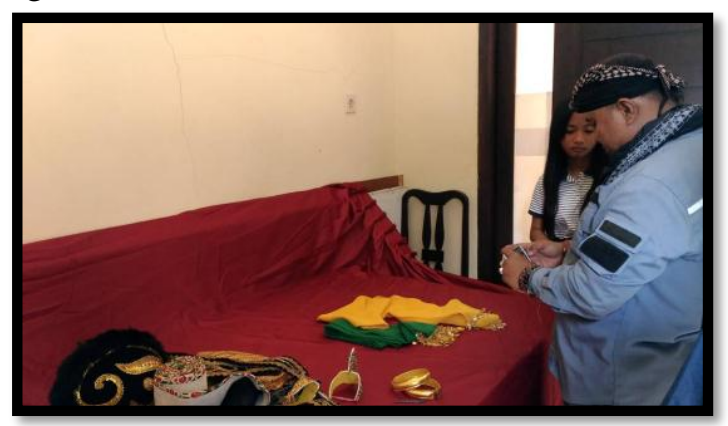

Gambar 12. Perekaman Video Pengajaran tentang Kostum Tari Klasik Menak Koncar

Kegiatan produksi ini dimaksudkan untuk memberi contoh video pembelajaran yang baik dan benar kepada peserta pelatihan. Diharapkan setelah produksi video ini akan menjadi barometer pembuatan video pengajaran tari khusus nya tari klasik.

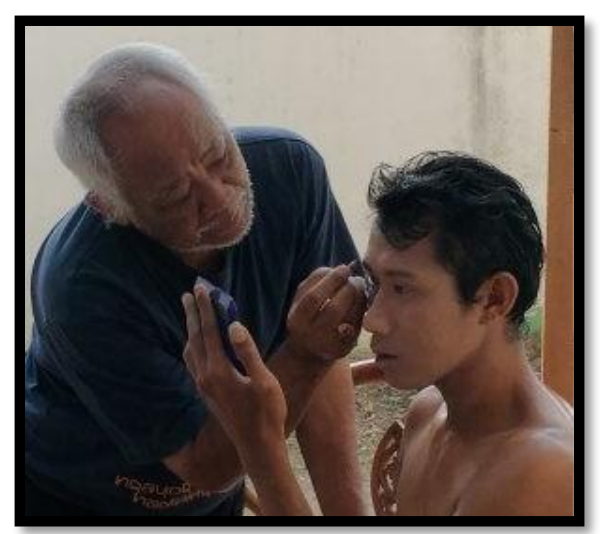

Gambar 13. Perekaman Video Pengajaran tentang Riasan Wajah Tari Klasik Menak Koncar 


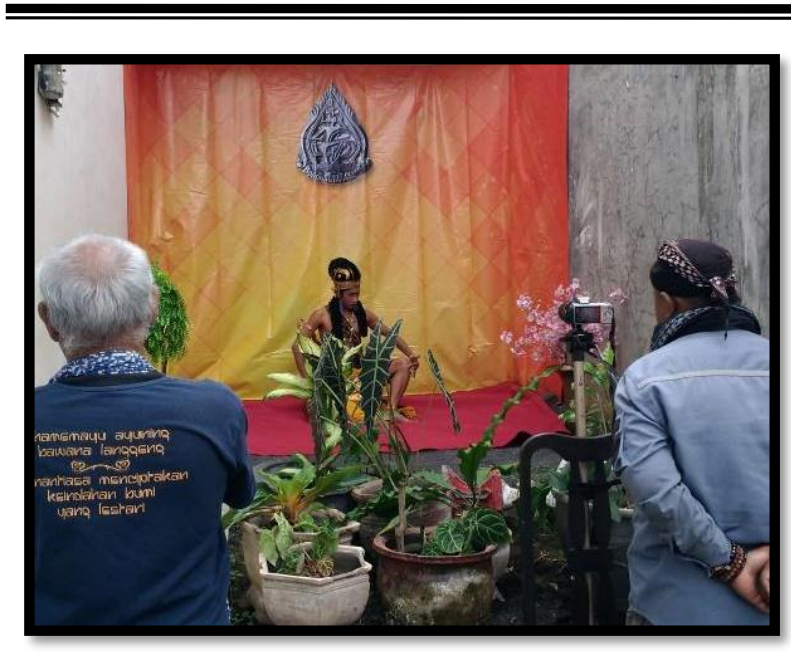

Gambar 14. Perekaman Video Pengajaran Tari Klasik Menak Koncar

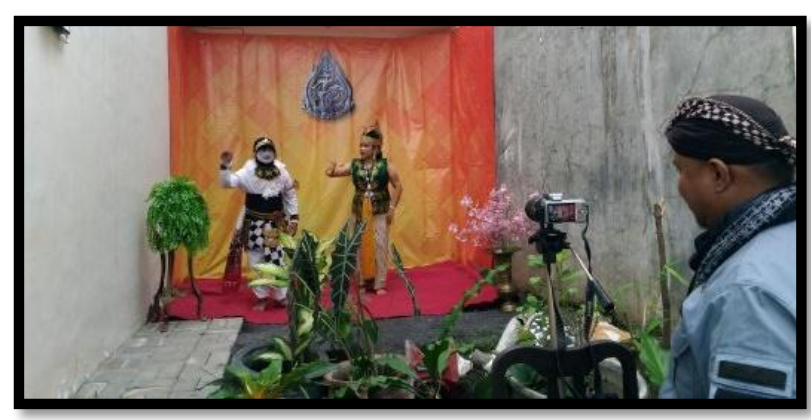

Gambar 15. Perekaman Video Pengajaran Tari Klasik Kethek Ogleng

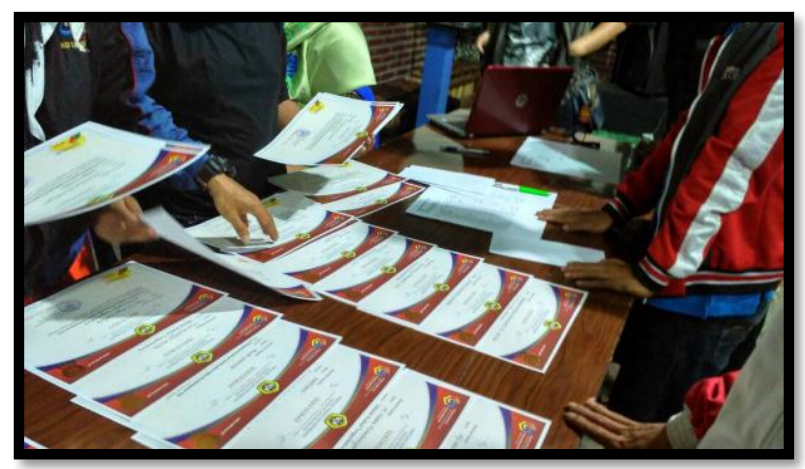

Gambar 16. Pembagian Sertifikat bagi Pemateri dan Peserta Pelatihan Video Pembelajaran Tari Klasik Wayang Orang

\section{KESIMPULAN}

\section{a. Kesimpulan}

Setelah pelatihan yang didapat, sanggar tari yang menjadi mitra dapat melakukan pembuatan video pembelajaran tari. Dengan demikian video pembelajaran tari ini dapat mempermudah siswa dalam mempelajari tarian, disamping itu sebagai sarana pelestarian seni tari yang semakin langka. Penyebaran budaya tari akan menjangkau masyarakat yang lebih luas.

\section{b. Saran}

1) Hendaknya sanggar tari dapat memproduksi video pembelajaran tari yang lebih banyak dengan berbagai macam tarian.

2) Kesenian Tari Wayang Orang dapat dilestarikan, terutama para maestro pengajar tari, keilmuannya dapat direkam menjadi video pembelajaran yang dapat disebarkan.

3) Bagi Perguruan Tinggi hendaknya lebih peka terhadap pelestarian kesenian dengan menyediakan pelatihan-pelatihan yang menunjang pembelajaran kesenian, khususnya seni tari.

\section{REFERENSI}

Binato, Iwan, "Multimedia Digital Dasar Teori dan Pengembangannya", Andi: Yogyakarta, 2010.

http://id.wikipedia.org/wiki/Wayang_orang

Nafitri, Melisa, Manajemen Sanggar Tari Pesona Nusantara di Kabupaten Lahat Provinsi Sumatera Selatan, Universitas Negeri Yogyakarta, 2012

Soetomo, Pemberdayaan Masyarakat, Pustaka Pelajar, Jogyakarta, 2011

Suyanto, M, "Analisis dan Desain Aplikasi Multimedia Untuk Pemasaran", Andi: Yogyakarta, 2004. 